Digital Press Social Sciences and Humanities

Strengthening Non-formal Education Institutions in Indonesia through Accelerating the Implementation of Information Technology Literacy

Tasril Bartin

Proceeding of The Non-Formal Education International Conference 2020

Alim Harun Pamungkas, Jamaris, Solfema (eds) 


\title{
Strengthening Non-formal Education Institutions in Indonesia through Accelerating the Implementation of Information Technology Literacy
}

\author{
Tasril Bartin \\ Department of Non-Formal Education Universitas Negeri Padang, Padang, Indonesia \\ e-mail: tasril_pls@yahoo.com
}

\begin{abstract}
Non-formal education is flexible, acts as a complement, substitute, and enhancer of knowledge and skills that are not obtained through formal education. However, during the 4.0 industrial revolution, it turns out that most of the services of informal educational institutions in Indonesia have not been maximized, especially in relation to the COVID-19 pandemic. Their learning services and institutional management are still conventional and business as usual. They are not able to adjust to the flow of information technology developments that are so fast. Conventional non-formal education institutions are unable to compete with digital-based non-formal education institutions which have generally not been established for a long time, even though their main business is not located in non-formal education services. This paper will theoretically examine the development of information technology literacy today, predict future opportunities and challenges, and what solutions should be implemented immediately by non-formal educational institutions by shifting service patterns from conventional education service systems to digital-based education service systems. Only with the massive changes in information technology, nonformal educational institutions can compete and can serve the maximum learning needs of society.
\end{abstract}

\section{Keywords}

information technology, literacy, nonformal education

\section{Introduction}

One of the crucial problems in most non-formal educational institutions today is the slow pace of nonformal education institutions in responding and adapting to the swift flow of information technology developments. However, non-formal education is very flexible, but the organizing institution has not been able to grasp every opportunity and opportunity that can be played out optimally. In fact, non-formal education can function as a substitute, enhancement, and complement to formal education in order to support lifelong education (Kemendikbud, 2020b).

We are currently in the era of the industrial revolution 4.0 at the same time in the era of the COVID 19 pandemic which has yet to show signs of ending. At this time humans are forced to follow changes in communication systems where human communication has started to shift from conventional communication systems (face-to-face) to virtual communication systems or in digital-based networks. In one aspect, this condition provides tremendous benefits because each person or every institution can save time, cost, and effort in the communication process. However, behind that, some problems arise later that are no less great than the benefits obtained. If the use of digital information technology or in networks in the community is not accompanied by changes in good behavior in communicating according to the rules for its use, then the chaos in the community will arise, social chaos will occur, and the monopoly of roles by certain parties in all fields, especially in the field of education. Therefore, in the future, the government should immediately make wise and fair regulations, protect and be able to serve the needs of all levels of society for all access to information and knowledge both in the formal education, non-formal and informal education channels.

This paper will discuss the implementation of information technology literacy in non-formal educational institutions, especially problems in the use of digital literacy or internet literacy in the world 
of non-formal education which includes concepts, characteristics, developments, problems in the use of information technology in society and in non-formal educational institutions, as well as various policies. government related to education.

\section{Concept and History of the Development of Information Technology Literacy}

Information technology literacy is a compound word consisting of two keywords, namely "Information Technology" and "Literacy". Unesco provides a simple definition of literacy where literacy is a person's ability to read and write. Then the experts developed this terminology further and combined it with the word "technology" which became known as "technological literacy". Thus technological literacy is defined as "the ability to understand and use technology as a tool to make it easy to achieve goals" (Bunz, 2009).

Furthermore, technological literacy is married again with information so that information technology literacy can be defined as a person's ability to work independently or with others by using equipment, resources, processes, and systems responsibly to access and evaluate information in any medium, and use that information to solve problems, communicate clearly, make informed decisions, and build new knowledge, products, or systems (Fortier, Potter, Grady, Lohr, \& Klein, 2000).

In the last three decades, the meaning and scope of literacy have expanded widely, including 1) literacy is a series of reading, writing and speaking skills, numeracy skills, and skills in accessing and using information; 2) literacy is a social practice whose application is influenced by context; 3) literacy is a learning process with reading and writing activities as well as a medium for contemplating, investigating, asking, and criticizing the knowledge and ideas being learned; and 4) literacy is a text that varies according to the subject, genre, and level of language complexity.

The process of developing information technology began with Charles Babbage's discovery of the computer in 1945, then developed into the internet era around 1969, then developed again by the United States Department of Defense (ARPA), then public use began in 1989. After that, it evolved again into the telephone. cellular was developed by Motorolla and subsequently developed again in the form of social media since 1997 as we feel today. In this regard, in Indonesia the National Literacy Movement was launched by the Government of the Republic of Indonesia in 2017 with a focus on 6 basic literacies that must be owned and understood by the community, namely: 1) literacy; 2) numeric literacy (numbers); 3) scientific literacy; 4) financial literacy; 5) cultural and civic literacy, and; 6) digital literacy.

\section{Characteristics of Information Technology Literacy and Digital Literacy}

Characteristically, information literacy has a closer bond with library science. He stressed the need for the careful collection and selection of the information available at work, at school, and in all aspects of personal decision making. Then in the learning process information literacy emphasizes critical thinking, meta-cognitive, and procedural knowledge that is used to search for information in certain domains and contexts. Thus information literacy can be interpreted as a way to carry out functions in complex communication situations.

In connection with that, the American Library Association-ALA (2000) states that everyone can be called information if that person has learned how to learn. They know how to learn, how to manage knowledge, how to understand and find information, and how to make good use of information so that others can learn from them. He is a person prepared for lifelong learning because he can always find the information necessary to carry out a task or make a decision.

Then media literacy has its own characteristics where it is more related to media content, the media industry, and social effects. Generally defined as the ability to access media, to understand and critically evaluate various aspects, and to have a critical approach to the media in terms of quality and accuracy of the content (e.g., being able to assess information, dealing with advertisements in various media, using search engines intelligently).

Meanwhile, digital literacy as a concept can be interpreted as the ability to integrate internet literacy and computer literacy. Meanwhile, information technology literacy as a concept is the ability to integrate internet literacy, computer literacy, and information literacy simultaneously (Lau \& Yuen, 2014). Then 
this ability is further developed into an ability to understand and be skilled in accessing, compiling, understanding, using, and disseminating information in various forms from a very wide variety of sources accessed through computers and the internet (Bawden, 2001; Belshaw, 2011; Gilster, 1997; UNESCO, 2004)

Information technology literacy can be explained from two points of view. First, technological literacy, previously known as computer literacy, namely literacy which refers to an understanding of digital technology including technical use and capabilities. Second, using information literacy. This literacy focuses on one aspect of knowledge, such as the ability to map, the ability to identify, the ability to process, and the ability to use digital information optimally.

\section{Description of Information Technology Use in Society and Non-Formal Education Institutions}

Coombs and Ahmed (1974) define that non-formal education is an alternative form of education for adults and children that occurs outside the formal school environment. Low RI No. 20/2003: NFE is an educational pathway that aims to replace, add, and supplement formal education. It can be held by a special institution appointed by the government based on national education standards. The results can be valued on a par with formal education. UNESCO defines that besides an addition, nonformal education is an alternative and or a supplement, non-formal education is institutionalized, intentional, and planned. The learning process is for a lifetime of individuals, serving people of all ages, unsustainable, of short duration.

The form can be literacy programs, education for adults and teenagers, children dropping out of school, life skills programs, work skills, Gender Mainstreaming, Women Empowerment, Education base Comunity, and social or cultural development. In some developing countries, nonformal education activities generally still focus on basic literacy and numeracy skills in the framework of providing basic education for all citizens. Besides focusing on adult literacy, non-formal education provides a place for basic education for school dropouts, life skills, job skills, and general culture. Non-formal education programs do not always follow the ladder system of different durations and may also not certify learning achieved.

There are many forms of non-formal educational institutions. In Indonesia are called Course and Training Institute (LKP), Community Learning Activity Center (PKBM), Learning Activity Center (SKB), Learning House (Panti Belajar), Vocational Training Center (BLK), Center for Religious Studies (Majelis Taklim), Center for Women's Studies (PSW), Early Childhood Education Programs (PAUD), NonGovernment Organizations, etc.

In its development, non-formal educational institutions have experienced ups and downs in accordance with government policies in each country. In Indonesia, non-formal education is not managed or fostered by a single ministry but is managed and fostered by various ministries and non-ministries. However, each ministry that manages and fosters non-formal educational institutions receives a different budget. Particularly in the ministry of education, private non-formal education institutions have received less attention compared to attention to educational institutions in the formal education pathway such as schools and universities. Therefore, to answer the challenges in the rapid development of information technology today and in the future, non-formal educational institutions must be encouraged by the government to be able to improve and adapt to the circumstances and situations that occur around them.

The massive use of information literacy technology is very important in non-formal education. This is important to balance the use of information technology, especially the very fast internet in the global world, including Indonesia. The data released by We Are Social (Riyanto, 2019) shows that nearly $50 \%$ of the world's population already uses the internet, Half of them are already active on social media. More use social media platforms: Facebook, Youtube, WhatsApp, FB messenger, WeChat, Instagram, Twitter. The daily time spent on social media are age $16-44$ years in $2014=1.44$ ', at the end of $2019=2.24$ '.

In Indonesia, the results of the APJII survey (Asosiasi Penyelenggara Jasa Internet Indonesia-APJII, 2018) show that most Indonesians use the internet, not for educational and personal development purposes. The purpose of using the internet for the Indonesian people is mostly for communication via messages $(24.7 \%)$, followed by social media needs $(18.9 \%)$, leisure time needs $(15.2 \%)$, to get job information (11.5\%), and watching movies and games (8.25\%). While the reasons people use the internet for self-development are, for example, to read the news (7\%), look for information and necessary 
data (4.25\%), for online sales and shopping (1.8\%), job demands (1.8\%), and access public services $(0.7 \%)$. Then, the maximum time spent using the internet in a day is $3-4$ hours $(14.1 \%)$, followed by $2-3$ hours (13.4\%), and for 1-2 hours (13\%). Meanwhile, the largest number of internet users are in the age range of $15-19$ years (91\%), then it is decreasing until the age range is 55-59 years (40\%).

In terms of the level of education in Indonesia, the most using the internet is the group of undergraduate-doctoral students (100\%), followed by groups currently studying high school (90.2\%), junior high school (80.4\%), and elementary school. (41.4\%). Then based on the jobs that mostly use the internet are entrepreneurs, teachers, and online merchants (100\%), followed by consulting services (94.7\%), students (92.1\%), and BUMN/ASN (civil servant) employees (89\%). and private / contract employees (83\%). Communication tools that are widely used daily are smartphones / cellphones (93.9\%), laptop computers (17.2\%), desktop computers $(9.6 \%)$, and tablets $(5.2 \%)$.

The data above means that the Indonesian people spend more of their time only on ordinary communication and enjoying entertainment, and use relatively little time for useful things to find work, build businesses, increase welfare, and improve the human resources of the community itself. Therefore, non-formal educational institutions can increase their role as education servants to increase community human resources for the welfare of themselves and their families. In practice, non-formal education managers must change the pattern of administrative services and education and training programs from a conventional face-to-face pattern to a digital-based service pattern. Media literacy skills or digital literacy are the main requirements for administrators and learning services in non-formal educational institutions. Various training programs can be designed on the platform Youtube, Facebook, Instagram, Twitter, and other applications that can be presented on the websites of government-owned and private training and community development institutions.

However, the digital-based pre-work training program provided by the Government of Indonesia in 2020 cannot be followed by many non-formal educational institutions because most of them do not have digital-based management services and programs. The collaboration is actually followed by non-formal educational institutions that have just been established and digital-based, such as Ruangguru.com, Schoolmu.com, Pintarmahir.com, Bukalapak.com, Tokopedia.com, Pitaria.com, Maubelajarapa.com, and Kemnaker.go. en. Therefore, the existence of non-formal education in the future is very much determined by the ability of managers and stakeholders to make maximum use of information technology.

\section{The Issue of Using Information Technology Literacy in Current Non-formal Education Institutions}

Several problems in the use of information technology literacy today in the general public can be identified as follows. First, the community's low willingness to use the internet for positive things: such as for training, recitation, information and knowledge, business promotion, and social care programs. Second, many people are trapped by negative internet behavior such as being consumed by hoaxes, addiction to pornography, sexual harassment, data theft, and fraud (skimming). Third, deliberate abuse for other purposes and not in accordance with the general benefit, such as political propaganda, fighting against each other between groups (in Indonesia it is called SARA), buzzers, acts of radicalism, cyberbullying, online pedophiles, and so on; and Fourth, the use of the internet is currently high cost, not all levels of society can enjoy it.

Then the problems in the current use of information technology literacy in several non-formal educational institutions in Indonesia can be identified as follows. First, the participation of non-formal educational institutions is minimal in welcoming government programs. Most of the non-formal educational institutions have not yet determined the direction and strategy in the application of information technology literacy, especially in determining service strategies in the COVID-19 pandemic. There are still many conventionally found student recruitment, for example, student registration is still manual, paying education fees with cash, learning time must be daytime and scheduled, teaching materials are still printed in the form of books or paper, there is no digital communication room, and minimal teaching materials digital. The existing non-formal educational institutions are expected to be able to manage and serve digital-based learning programs.

Second, the lack of pro-institutional PNF policies to increase their capacity. Job training institutions such as Course Institutions, Vocational Training Centers (BLK), Community Learning Activity Centers (PKBM) are still conventional in serving training, there has not been any massive information technology- 
based learning program, either pre-pandemic COVID-19 or during the COVID-19 pandemic. They are neither responsive to change nor encouraged to change.

Third, the pre-employment card program offered by the government is only enjoyed by private institutions/consortia with digital platforms, added to the Ministry of Manpower. Registrants were 8.6 million people, participants accepted were in total of 168,111 (batch 1), and 288,154 (batch 2). The trainings that are offered in order: English / TOEFL, side business training during COVID-19, staff/admin training, online shop business on social media, graphic design, and building a culinary business/coffee shop. Case in point, of the 19,000 course and training institutions (LPK and LKP) throughout Indonesia, only 147 LKP/LPK provide paid online courses and join the pre-employment card program, in details, 111 organizers are in the form of institutions, and 36 others are scattered individuals. in 8 preemployment card partner digital platforms.

\section{Solutions Offered for Non-formal and Informal Education}

Based on the above problems, several things that can be offered as alternatives in reducing the slowness of non-formal educational institutions to rise and be able to adapt to the existing situation are:

\subsection{Wise Use of IT Literacy in Society}

To reduce the negative impact of internet use in society, comprehensive and sustainable government policies are needed, especially to provide education to the wider community, namely by accelerating the National Literacy Movement (GLN) in various government agencies and communities. Then accelerate the socialization of Law Number 11/2008 as amended by Law No19/2016 on Electronic Information and Transactions (ITE), and provide counseling for the correct use of social media. The ultimate goal is the realization of "information ethics" in society, namely, awareness to evaluate various issues related to the dissemination of electronic data. This includes how to filter hoaxes, sort information, and how to convey information properly. In turn, the minimization (zero cases) of police reporting will be achieved as a result of being caught in the ITE Law.

\subsection{Strengthening the Capacity of Non-formal Education Institutions}

In the reference book for Indonesia's digital literacy framework (Kemendikbud, 2020a), there are three main parts that internet users need to understand, namely the protection section, the rights section, and the empowerment section. One of the areas that should concern non-formal educational institutions is the empowerment section. This section can help internet users to produce work and performance that are more productive and meaningful for themselves, the environment, and the wider community.

In this section, several topics become a challenge, including quality citizen journalism, entrepreneurship related to the use of information and communication technology (ICT) and/or digital products, such as those carried out by technopreneurs, actors digital start-ups and owners of Micro, Small and Medium Enterprises (MSMEs). This section also emphasizes specific matters relating to information ethics that highlight hoaxes, disinformation, and hate speech, as well as efforts to deal with them by selecting information, wise while online, think before posting. Non-formal educational institutions can play a role in educating citizens about how to become citizen journalists, for example reporting on culinary programs, tourism objects, book reviews, and so on. Then in the entrepreneurial aspect, nonformal educational institutions can help the community in empowering Micro, Small, and Medium Enterprises (MSMEs) and promoting their products, helping to build digital start-ups, and developing their own online market.

Therefore, in this part of empowerment, the government should be able to encourage all PNF institutions to make major changes from conventional face-to-face training patterns to online or digitalbased training patterns. Non-formal educational institutions under the guidance of the government can drive change in all fields because they are financed by the state. Some of the main things that need to be improved are infrastructure, curriculum, and human resources. 


\subsection{Provision of Public Internet Facilities}

Currently, the internet has become a secondary necessity, which is almost always needed by the community, both for regular communication access, educational services, helping business activities, entertainment services, and various other activities. With the existence of free public internet facilities, people who are classified as poor can be helped, especially for the needs of online learning which are being intensively promoted by the government in the current atmosphere of the COVID-19 pandemic.

The availability of internet facilities that can be enjoyed by the public easily, for free or on subsidies is a necessity in a country that wants to be developed and prosperous. This is important so that people can access all the content provided by non-formal educational institutions, including the availability of free ebooks for certain groups. Several regions in Indonesia, such as eastern Indonesia, have not fully received good internet access services. Likewise, most rural areas in several areas in Sumatra, Sulawesi, and Kalimantan have not been reached by internet services. This will make people fall behind in access to information and other non-formal education.

It seems that a radical change is needed from the perspective of education management in Indonesia. It is time for policy reforms to be carried out for the three education channels, namely by encouraging the central and regional governments to make non-formal and formal education equal and balanced. The nonformal education target group also includes those who have enjoyed formal education services, namely when they are already at home, in the community, and at non-formal educational institutions. They also need access to educational content at various non-formal educational institutions. Developed countries in Europe such as Germany, Denmark, Finland have long been concerned with non-formal education, namely by providing sufficient budgets for operational costs, human resource development, and educational infrastructure.

\section{Conclusions}

Information Technology has penetrated all aspects of our lives, so we must be able to accept and use information technology developments smartly. The national literacy movement did not go as expected. Therefore, the program must be accelerated to all lines, for example by providing public internet services widely and giving information to the public about the use of social media. Non-formal education institutions are not ready for changes in information technology because they have to change themselves with digital or online education program services. The government should make balanced and equal policies on three education channels; formal education, nonformal education, and informal education.

\section{References}

American Library Association-ALA. (2000, July). Information Literacy Competency Standards for Higher Education. Retrieved July 2, 2013, from

http://www.ala.org/acrl/sites/ala.org.acrl/files/content/standards/standards.pdf

Asosiasi Penyelenggara Jasa Internet Indonesia-APJII. (2018). Survei Nasional Penetrasi Pengguna Internet Tahun 2018. Jakarta: APJII.

Bawden, D. (2001). Information and digital literacies: a review of concepts. Journal of Documentation, 57(2), 218-259. https://doi.org/10.1108/EUM0000000007083

Belshaw, D. A. J. (2011). What is digital literacy? A Pragmatic investigation. Durham University United Kingdom.

Bunz, U. (2009). A Generational Comparison of Gender, Computer Anxiety, and Computer-Email-Web Fluency. SIMILE: Studies In Media \& Information Literacy Education, 9(2), 54-69. https://doi.org/10.3138/sim.9.2.003 
Coombs, P. H., \& Ahmed, M. (1974). Attacking Rural Poverty: How Non-Formal Education Can Help. Baltimore: Johns Hopkins University Press.

Fortier, J. D., Potter, C. J., Grady, S. M., Lohr, N. J., \& Klein, J. (2000). Wisconsin's Model Academic Standards for Information and Technology Literacy. Wisconsin. USA: Wisconsin's Model Academic Standards for Information and Technology Literacy. Wisconsin Departement of Public Instruction Madison.

Gilster, P. (1997). Digital literacy. New York: Wiley Computer Pub.

Kemendikbud. (2020a). Buku Literasi Digital. Retrieved from https://gln.kemdikbud.go.id/glnsite/buku-literasidigital/

Kemendikbud. UU No. 20 Tahun 2003 Tentang Sistem Pendidikan Nasional. , (2020).

Lau, W. W. F., \& Yuen, A. H. K. (2014). Developing and validating of a perceived ICT literacy scale for junior secondary school students: Pedagogical and educational contributions. Computers \& Education, 78, 1-9. https://doi.org/10.1016/j.compedu.2014.04.016

Riyanto, A. D. (2019). Hootsuite (We are Social): Indonesian Digital Report 2019. Retrieved from https://andi.link/hootsuite-we-are-social-indonesian-digital-report-2019/

UNESCO. (2004). The Plurality of Literacy and its Implications for Policies and Programmes: Position Paper. Retrieved from http://unesdoc.unesco.org/images/0013/001362/136246e.pdf 